\title{
Fiscal Policy Effects and Capital Mobility in Latin American Countries
}

\author{
Jose U. Mora* \\ Pontificia Universidad Javeriana - Cali, Colombia \\ Rafael A. Acevedo \\ Texas Tech University, USA
}

\begin{abstract}
This paper studies the relationship between the size of the fiscal multiplier and the degree of capital mobility in some Latin American countries. Mundell's (1963) and Fleming's (1962) models show that this effect could be very large or small (close to zero) depending on the exchange rate and the degree of capital mobility, and the potency of a fiscal policy is inversely correlated with the degree of capital mobility. Based on Mora's (2013) model, we argue that the multiplier might not be negatively correlated with capital mobility in these countries. In other words, the potency of fiscal policy could be small because the degree of capital mobility in Latin American countries is quite low. The empirical findings support our hypothesis. We have found that the size of the fiscal multiplier tends to increase or (at least) to remain around 1.40 in these countries in the short run; however, in the long run, this effect tends to decrease significantly to 0.34 . These results also suggest that the effectiveness of fiscal policies in Latin American countries are still large but could be larger if they become more financially integrated with the rest of the world.
\end{abstract}

JEL Classifications: E62, E12, F41, O54

Keywords: Fiscal policy, Business cycles, Latin America

\footnotetext{
* Corresponding author: Jose U. Mora; Professor, Department of Economics, Pontificia Universidad Javeriana - Cali, Calle 18 (av. Cañas Gordas)\# 118 - 250, Cali. Valle del Cauca, Colombia. Tel: 5723218200 ext 9055. E-mail: jose.mora@javerianacali.edu.co
} 


\section{Introduction}

After the 2008 2009 crisis, there was an important surge in developed and developing countries when it came to the use of fiscal instruments for recovering their economies. This phenomenon brought attention to a discussion on the effectiveness of fiscal policies and, more particularly, the size of the fiscal multiplier. However, there is no consensus. On the one side, some economists argue that the size of the multiplier is not the same among countries. It varies across countries and over time, and these variations are determined by factors such as the exchange rate, degree of openness and capital mobility, foreign debt as a percentage of GDP, and stability and flexibility of the financial system (Corsetti, Meier, and Muller 2012). On the other side, there is no agreement among economists regarding the size of the multiplier within a country. In this sense, the best example is the United States, where economists take different positions regarding the effectiveness of the 787,000 US million dollars approved by the U.S. congress in February 2009. On the one side, Christina Romer, Director of the Economic Council Advisors at that time, argued that the multiplier was relatively large and used a multiplier of 1.6 to compute the impact of this fiscal aid on the economy (Romer and Bernstein 2009). On the other side, Robert Barro (2009) pointed out that during peace time the multiplier was zero and henceforth the fiscal stimulus would be ineffective. Had this been the case, the U. S. economy would not have recovered 3.7 million jobs by the end of 2010 (Ilzetski, Mendoza and Végh 2013).

Why is the multiplier of fiscal policy so important in an increasingly integrated world? The answer lies in the extensions of the Keynesian model and the contributions of Mundell (1963) and Fleming (1962). The Keynesian model predicts that the more open an economy, the smaller the size of its multiplier and the lower the potency of its fiscal policy. More particularly, this theory suggests that the increase in real output induced by an expansionary fiscal policy leaks through imports, reducing the effectiveness of the fiscal policy when the marginal propensity to import is high. However, the effectiveness of the fiscal policy will be higher (up to the highest) if the marginal propensity to import is low (down to zero, the closed economy). The Mundell-Fleming model showed that this effect might be very large or small (close to zero) depending on the exchange rate and the degree of capital mobility. Moreover, it demonstrated that potency of a fiscal policy was inversely correlated with the degree of capital mobility. More precisely, in small, open economies under floating exchange rates and perfect capital mobility, a fiscal expansion causes an increase in income and interest rates that produces an appreciation of the domestic currency and, as a result, diminishes or eliminates the stimulus of the fiscal policy. By the same token and under floating exchange rates, the lower the degree of capital mobility, the higher the effectiveness of fiscal policy. Nevertheless, if the economy faces a fixed exchange rate, then the degree of capital mobility enhances the potency of fiscal policy.

This topic is fundamental for Latin American countries, since fiscal reforms in these countries are very common. The implicit assumptions in the Mundell-Fleming and Keynesian models are that the economy is fully diversified, no production sector is more important than another, and domestic financial markets are fully integrated into the world financial system. 
Latin American countries, on the contrary, operate very differently from those assumptions. These are economies characterized by the dominance of one or two economic activities that contribute to the bulk of exports. In this sense, Mora (2013) built a theoretical model of aggregate demand and supply for small open economies, like Latin American economies. Under the assumptions of floating exchange rate and imperfect capital mobility, the study found that the potency of fiscal policy is positively correlated with the degree of capital mobility. This result is in conflict with the Mundel-Fleming and Keynesian models. As a result, the effectiveness of fiscal policy in Latin America might be limited by these countries' low capital mobility. If this hypothesis holds, then any fiscal reform implemented to make an economy grow faster might produce little or no benefits at all on the overall economic activity; only higher inflation rates and domestic currency depreciations will prevail. Therefore, opening their economies to the rest of the world is desirable, as is integrating their financial markets into the world financial system, at least in the short run.

This paper aims to study the relationship between the size of the fiscal multiplier, openness, and capital mobility in Latin American countries. We use panel data collected from the Penn World Table and World Bank for 12 countries for the period 1980 2014. The empirical results suggest that there are fixed effects and random effects affecting the size of the multiplier across countries and over time. This implies that fiscal policy might be effective in changing real outputs. These results are very important because the size of the multiplier and how it behaves over time gives us precise ideas on when and how to use fiscal policy in order to stabilize or stimulate the Latin American economies over the different phases of business cycles.

This paper is organized as follows. The following section discusses the literature. Section three presents the theoretical model from which we derive our hypothesis. Next, Section four discusses the empirical method and presents the estimated results. Finally, Section five presents the conclusion.

\section{Literature Review}

During and after the recent financial crisis, several developed and developing countries have been using expansionary fiscal policies, namely, increasing government spending or reducing taxes, to stabilize or stimulate their economies. These have brought significant attention to the research of economic policy on the impact of the fiscal multiplier (i.e., the size of the fiscal multiplier). However, there is no consensus on this issue. Firstly, for most economists, the value of the multiplier is not the same for all countries. Its value depends on characteristics such as openness to foreign trade, percentage of debt to GDP, exchange rate, degree of capital mobility, and health of the financial system. Corsetti, Meier, and Muller (2012) argue that these characteristics may affect the effectiveness of fiscal policy to change domestic outputs. Second, even within one country, economists disagree on the size of the multiplier and its effectiveness, as pointed out by the debate between Romer and Bernstein (2009) and Robert Barro (2009). The size of the multiplier could be very low during 
peacetime as pointed out by Barro (2009) and Barro and Redlick (2011), who argue that the size of the multiplier would depend on the state of the economy.

Although the literature on this topic is growing very rapidly, we will discuss the most relevant and recent papers for this research. A large number of papers estimated the size of fiscal multipliers, mostly for the United States (Whalen 2015, Ramey and Zubairy 2014, Owyang, Ramey, and Zubaire 2013, Auerbach and Gorodnichenko 2012a, Mustea 2015, and Batini, Eyraud, Forni, and Weber 2014; among others), and for other developed and developing economies (Auerbach and Gorodnichenko 2012b, Batini et al. 2014). However, studies on Latin America are few except for Fraga, Briceño, and Heras (2016) on large Latin American economies, Puig (2014) on Argentina, Moura (2015) and Costa and Vaz Sampaio (2016) on Brasil, and Laverde (2010) on Colombia. These studies use mostly VAR techniques and DSGE models to compute the short- and long-run fiscal multipliers.

The size of the multiplier depends on several characteristics, such as the state of economic activity, response of monetary policy to fiscal policy, openness to international trade, exchange rate, foreign debt, and financial system health. Auerbach and Gorodnichencko $(2015,2012 a)$ argue that the economic state might affect the size of the multiplier, which implies that this could be higher during recessions when unemployment is high, or when the interest rate is near the zero-lower bound (also from Woodford 2011, Eggertsson 2011, and Christiano et al. 2011). Auerbach and Gorodnichencko (2012a) employed an SVAR model that allows differentiated responses across recessions and expansions and uses the switching model to compute the government spending multiplier for the United States. They found that the multiplier could be 2.5 during recessions and 0.6 during expansions. These results could be attributed to the fact that when the economy was near full capacity, fiscal policy effectiveness would be mitigated by a reduction in private-sector spending. However, when resources were abundant, the impact of the fiscal stimulus would be magnified by additional spending in the private sector. Auerbach and Gorodnichenko (2012b) extend the analysis, using an expectations-augmented VAR for a large number of Organization for Economic Cooperation and Development (OECD) countries. Their findings confirmed their previous finding that multipliers were larger during recessions than during expansions. Other studies, including those by Fazzari et al. (2014) and Baum et al. (2012), used different types of VAR models and also found that fiscal multipliers were larger in economic contractions than in expansions.

On the contrary, Owyang et al. (2013) and Ramey and Zubairy (2014) used data sets for the United States and Canada that extended beyond the Great Depression (even to the late 1800s) and applied a narrative approach to analyzing the effectiveness of government spending in the presence of military events. They showed that in the United States, fiscal multipliers were not higher during economic recessions, whereas in Canada, the evidence suggested that multipliers were significantly higher in the presence of economic slack (Owyang et al. 2013). Ramey and Zubairy (2014), assuming that longer periods of data might contain more information, used a data set for the United States dating back to 1889. They found that some of the most cited findings about the size of the multiplier (due to the way they are computed) were not robust for generalization. Second, they found no evidence that 
the U.S. government expenditure multiplier was high in the presence of economic slack. Third, their findings about the larger multipliers (when the economy was near the zero-lower bound) were related to the exclusion of the WWII period; however, these estimates were imprecise and not robust for generalization.

Hall (2009), Christiano, Eichenbaum, and Rebelo (2011), Davig and Leeper (2011), and Coenen et al. (2012) found that the size of the fiscal multiplier might be limited by the Federal Reserve when it increases the federal funds rate as a countermeasure to inflationary pressure under normal economic conditions. However, they argued that the fiscal policy effectiveness might be higher sometimes, e.g., when the monetary policy was restricted by the zero-lower bound interest rate.

The exchange rate, public indebtedness, and health of the financial system might also affect the multiplier effect. Corsetti et al. (2012) used a panel for 17 OECD countries covering the period from 1975 to 2008. They performed an estimation in a two-step procedure, identifying fiscal shocks as residuals from an estimated spending rule, and then used these residuals to trace their macroeconomic effects under different conditions: exchange rate, public debt, and health of the financial system. Under a positive fiscal shock, the unconditional response confirmed the results reported in literature. The conditional response differed systematically across different exchange rates, given that real appreciation and foreign deficits occurred mainly under currency pegs. Additionally, output and consumption multipliers were relatively high during a financial crisis. They suggested that this happened because private spending was more likely to be restricted due to limited credit access during the financial crisis. Karras (2011) investigated the impact of the exchange rate on the size of the fiscal multiplier for 61 developed and developing countries, using annual panel data from 1951 to 2007. Empirical results showed that fiscal expansions were more effective under both exchange rates in the short run than in the long run. Moreover, the multiplier was higher under fixed exchange rates than under floating. He argued that consumption was in fact a key variable because government spending crowded out private spending under flexible exchange rates, while under fixed exchange rates, private consumption increased.

Karras (2012) investigated whether fiscal policy effectiveness depended on trade openness, using panel data from 1951 to 2007 for 62 developing and developed countries. Trade openness was defined as the sum of exports and imports as a percentage of GDP. The sample included a variety of countries that exhibited different degrees of trade openness among them and over time. The empirical estimates indicated that trade openness negatively affected the effectiveness of fiscal policy, particularly pointing out that an increase of $10 \%$ of GDP reduced the fiscal multiplier by approximately $5 \%$ to $6 \%$. Similar results were found by Yang (2016) in a study that considered financial openness. In this context, financial openness was in some sense a proxy for capital mobility as we use it in our paper. However, in our paper, we test the relationship for Latin American countries using a different specification.

It is also important to point out that different types of government spending might produce different impacts on the economy. For instance, Gechert (2015), based on meta-regression analysis over 104 papers that provide 1063 multiplier values, performed a panel regression analysis over the entire sample and different subsamples. On average, the estimated multiplier 
was around 0.73 and could vary between 0.09 to 1.4 , depending on the specification, methods, and control variables. Particularly, this variation came from public investment which increased the average multiplier by 0.6 , whereas taxes and transfers lowered it by 0.3 to 0.4 units.

Ilzetzki, Mendoza, and Végh (2013) used the SVAR approach with quarterly data for 44 developed and developing countries from the first quarter of 1960 to the fourth quarter of 2007. Their results indicated that in most cases, the effect of government consumption was very small in the short run (first quarter). In open economies with floating exchange rates, the multiplier was negligible, with no effect in the long run. However, the long-run impact was significant if the economy was closed and had fixed exchange rates. Furthermore, a fiscal stimulus in high-indebted countries (more than $60 \%$ of GDP) might lead to strong negative effects on outputs.

Finally, it is important to emphasize that the literature showed different results for the size and effectiveness of the fiscal multiplier in the short and long run. Most of the results were for developed countries whose economies differed from that of Latin America. Therefore, this paper aims to fill the gap in the literature on the size of fiscal multipliers in Latin America.

\section{The Theoretical Model}

Although the Mundell-Fleming model (Mundell 1963 and Fleming 1962) made an interesting starting point, it was an aggregate demand model. It rested on the assumptions that the price level was constant and the aggregate supply was perfectly elastic at the equilibrium price level. As a result, there was no inflation. Those would be very restrictive assumptions if we wanted to analyze Latin American economies where inflation had been an important phenomenon during the last 38 years. This paper aims to expand this model, allowing prices (and salaries) to vary and representing the majority of Latin American countries where one or two production sectors dominate the economy.

\section{A. Assumptions}

According to Mora (2013), suppose that there is a small open economy with two production sectors: sector 1 extracts, produces, and exports a single raw material or commodity (be it crude oil, copper, coffee, or any other mineral or agricultural product) that is very important for the economies of the world. Its price, $p_{1, t}^{*}$, is determined in international markets, and the domestic economy takes such a price as given. Sector 2 produces a composite good that can only be sold and consumed in the domestic market at a price of $p_{t}$. Finally, given that the economy is small and it is not fully integrated into the world of financial markets, let's assume there is imperfect capital mobility between the domestic economy and the rest of the world.

Contrary to the Mundell-Fleming model, let's assume that prices are relatively flexible and that workers are unionized, using the consumer price index (CPI) to negotiate about their 
wages for each period. Suppose that the CPI is computed as follows:

$$
C P I_{t}=\left(E P_{t}^{*}\right)^{v}\left(p_{t}\right)^{1-v}
$$

where $v, P_{t}^{*}, P_{t}$, and $E$ are the weight that domestic prices receive in the CPI index, the foreign price level, the domestic price level, and the nominal exchange rate (domestic currency per US dollar), respectively. Wages in each sector are indexed according to the following equation:

$$
W_{i, t}=\bar{\omega}_{i} C P I_{t}=\bar{\omega}_{i}\left(E P_{t}^{*}\right)^{v}\left(p_{t}\right)^{1-v}
$$

where $0 \leq \bar{\omega}_{i} \leq 1$ is the weight used for salary indexation in sector $i$. If $\bar{\omega}_{i}=0$, wages in sector $i$ are rigid and do not change; if $\omega_{i}=1$, then wages in sector $i$ are completely flexible and adjust instantaneously with the change in the CPI. Taking $\operatorname{logs}^{1}$ of Equation (2), we obtain:

$$
w_{i, t}=\bar{\omega}_{i}+v e+v p_{t}^{*}+(1-v) p_{t}
$$

Following Mora (2013), let's assume that firms in both sectors are profit maximizers and use Cobb-Douglas constant returns to scale technologies. Under this optimizing behavior, the aggregate supply function would be:

$$
\begin{aligned}
y_{t}= & \left(\theta_{2}-\theta_{1}\left(\frac{1-v}{v}\right)\right) p_{t}-v\left(\theta_{1}+\theta_{2}\right) p_{t}^{*}-\left(\theta_{1}+\theta_{2}\right) \bar{\omega}_{i} \\
& -\left(\theta_{2}-\theta_{1}\left(\frac{1-v}{v}\right)\right) e+k_{1}+k_{2}+\theta_{2} \ln (1-\varphi) \\
& +\theta_{1} \ln (1-\theta)+\theta_{1} p_{1, t}^{*}+\frac{1}{\theta} z_{1, t}+\frac{1}{\varphi} z_{2, t}
\end{aligned}
$$

where $k_{1}$ and $k_{2}$ are constants that represent the (logs of) capital stocks, $p_{1, t}^{*}$ is the world price of the tradable good, and $z_{1, t}$ and $z_{2, t}$ are supply shocks in each production sector, respectively. This function has a positive slope in the space $(y, p)$ as long as $\theta_{2}-\theta_{1}\left(\frac{1-v}{v}\right)>0$. Likewise, if the supply function has a positive slope, then a depreciation of the domestic currency would cause an increase in production of the tradable (exporting) good and a contraction in output in the other sector, reducing aggregate total output, since $-\left(\theta_{2}-\theta_{1}\left(\frac{1-v}{v}\right)\right)<0$.

Aggregate demand is determined by the simultaneous equilibria in the real market, the money market, and the foreign market, given the last by the balance of payments balance. The real market equilibrium is given by the following equation (in logs):

${ }^{1}$ From now on, lowercase letters are used for natural logs of variables, except when the contrary is indicated. 


$$
y_{t}=\sigma_{p} p_{1, t}^{*}+\alpha\left(e+p_{t}^{*}-p_{t}\right)-\gamma r_{t}+\sigma_{f} y_{t}^{*}+z_{I S}
$$

where $y_{t}^{*}$ is the log of foreign real output ${ }^{2}, r$ is the real interest rate, and $z_{I S}$ is a real shock $\left(z_{I S} \sim\left(0, \sigma_{z_{I S}}^{2}\right)\right)$. In this paper, this shock would be associated with a fiscal expansion.

The money market equilibrium requires that demand equals supply for real balances:

$$
m_{t}-p_{t}=\beta_{0} y_{t}-\beta_{1} i_{t}+z_{M}
$$

where $m_{t}$ is the natural logarithm of the stock of money, $\beta_{0}, \beta_{1}>0$ are, the elasticity of real income $y_{t}$, and the semi-elasticity of the nominal interest rate $i_{t}$, respectively, and $z_{M}$ is an unanticipated shock in the money market. Note that the interest rate is the ex-ante nominal rate and is determined as follows:

$$
i_{t}=r_{t}+\pi^{e}
$$

where $\pi^{e}$ is the expected value in period $t$ of the inflation rate in period $t+1$. In order to simplify the analysis, suppose that inflation expectations are adaptive, i.e., $\pi^{e}=\pi_{t-1}$. Substitute this result into the previous equation and then into Equation (6), and the money market equilibrium will be given by:

$$
m_{t}-p_{t}=\beta_{0} y_{t}-\beta_{1} r_{t}-\beta_{1} \pi_{t-1}+z_{M}
$$

Finally, we need to obtain the foreign market equilibrium. Considering imperfect capital mobility, foreign market equilibrium will be given by the balance of payment equation as follows:

$$
B_{t}=\sigma_{p_{1, t}^{*}} p_{1, t}^{*}+\sigma_{x}\left(e+p_{t}^{*}-p_{t}\right)+\sigma_{f} y_{t}^{*}-\sigma_{y} y_{t}+z_{E X}+\lambda\left(r-r^{*}\right)=0
$$

where $\sigma_{p_{1, t}^{*}}, \sigma_{x}, \sigma_{f}$, and $\sigma_{y}$ are the balance of payment elasticities with respect to the tradable good's price, real exchange rate $\left(e+p_{t}^{*}-p_{t}\right)$, foreign real output, $y_{t}^{*}$, and domestic real income, respectively. $\lambda$ stands for the degree of capital mobility and $\lambda>0$. For instance, $\lambda$ equals zero, implies that there is no capital mobility between foreign and domestic financial markets; conversely, a very large value of $\lambda(\lambda=\infty)$ implies that there are no barriers for financial transactions - foreign and domestic assets are perfect substitutes for one another. Again, as in previous cases, $z_{E X} \sim\left(0, \sigma_{z_{E X}}^{2}\right)$.

Equations (4), (5), (7), and (8) conform to a system of equations that represent the aggregate supply and demand of this economy. Since the system is linear, we can totally differentiate the system and use matrix algebra to find the effects of any shock on the economy.

${ }^{2}$ The main trading partner for many Latin American economies is the United States. 


\section{B. Theoretical results}

According to this model, a domestic fiscal expansion will produce the following results. Let $|D|=-\left(\sigma_{x} \gamma+\alpha \lambda+\left(\theta_{2}-\theta_{1}\left(\frac{1-v}{v}\right)\right)\left(\gamma \sigma_{y}+\lambda\right)\right)<0$ be the determinant of the coefficient matrix of the system. Then, by Cramer's rule, the results of a fiscal policy shock are as follows:

$$
\begin{gathered}
\frac{d y_{t}}{d z_{I S}}=\frac{-\lambda\left(\theta_{2}-\theta_{1}\left(\frac{1-v}{v}\right)\right)}{|D|}>0 \\
\frac{d p_{t}}{d z_{I S}}=\frac{-\sigma_{x} \beta_{1}+\left(\theta_{2}-\theta_{1}\left(\frac{1-v}{v}\right)\right)\left(\lambda \beta_{0}-\sigma_{y} \beta_{1}\right)}{|D|} \gtreqless 0 \\
\frac{d e_{t}}{d z_{I S}}=\frac{\left(\lambda-\sigma_{x} \beta_{1}+\left(\theta_{2}-\theta_{1}\left(\frac{1-v}{v}\right)\right)\left(\lambda \beta_{0}-\sigma_{y} \beta_{1}\right)\right)}{|D|} \gtreqless 0 \\
\frac{d r_{t}}{d z_{I S}}=-\frac{\left(\sigma_{x}+\sigma_{y}\left(\theta_{2}-\theta_{1}\left(\frac{1-v}{v}\right)\right)\right)}{|D|}>0
\end{gathered}
$$

Equations (9) and (12) show the expected results of a government spending increase, while Equations (10) and (11) show mixed signs. However, these signs will depend upon the signs of $\lambda \beta_{0}-\sigma_{y} \beta_{1}$ and $\lambda-\beta_{1} \sigma_{x}$. If an economy has low capital mobility, i.e., $\lambda \beta_{0}<\sigma_{y} \beta_{1}$ and $\lambda<\beta_{1} \sigma_{x}$ as a result, $\frac{d e_{t}}{d z_{I S}}>0$ and $\frac{d p_{t}}{d z_{I S}}>0$. This means that an expansionary fiscal policy will cause an increase in the domestic price level and the nominal exchange rate. If, on the contrary, the economy has high capital mobility, i.e., $\lambda \beta_{0}>\sigma_{y} \beta_{1}$ and $\lambda>\beta_{1} \sigma_{x}$, then $\frac{d e_{t}}{d z_{I S}}<0$ and $\frac{d p_{t}}{d z_{I S}}<0$. These results imply that an increase in government spending will cause a fall in the domestic price level and the nominal exchange rate.

Even though these results are important, the main contribution of this paper comes from the magnitude of the result in Equation (9), which is the fiscal policy effect on real output. To see how capital mobility affects the size and sign of this effect, let's take the derivative of $\frac{d y_{t}}{d z_{I S}}$ with respect to $\lambda$. 


$$
\frac{\partial\left(\frac{d y_{t}}{d z_{I S}}\right)}{\partial \lambda}=\frac{\left[\theta_{2}-\theta_{1}\left(\frac{1-v}{v}\right)\right]\left[\sigma_{x} \gamma+\gamma \sigma_{y}\left(\theta_{2}-\theta_{1}\left(\frac{1-v}{v}\right)\right)\right]}{\left[\sigma_{x} \gamma+\alpha \lambda+\left(\theta_{2}-\theta_{1}\left(\frac{1-v}{v}\right)\right)\left(\gamma \sigma_{y}+\lambda\right)\right]^{2}}>0
$$

This is a very important result with significant implications for Latin America. It states that the degree of capital mobility enhances the potency of fiscal policy. Therefore, it is expected that the potency of fiscal policy might be limited, since most countries' domestic financial markets are not well integrated into the world, i.e., a relatively low capital mobility. Besides, as Equations (14) and (15) below show, the lower the degree of capital mobility, the higher the costs of the domestic currency (due to inflation and depreciation) during a fiscal expansion. These results are consistent with some historical events in Latin American economies.

$$
\begin{aligned}
& \frac{\partial\left(\frac{d p_{t}}{d z_{I S}}\right)}{\partial \lambda}=\frac{\left[\theta_{2}-\theta_{1}\left(\frac{1-v}{v}\right)\right]\left[-\beta_{0} \sigma_{x} \gamma-\sigma_{x} \beta_{1}-\alpha \sigma_{y} \beta_{1}\right]\left[\theta_{2}-\theta_{1}\left(\frac{1-v}{v}\right)\right]^{2}\left[-\sigma_{y} \beta_{1}-\beta_{0} \gamma \sigma_{y}\right]-\sigma_{x} \beta_{1} \alpha}{\left[\sigma_{x} \gamma+\alpha \lambda+\left(\theta_{2}-\theta_{1}\left(\frac{1-v}{v}\right)\right)\left(\gamma \sigma_{y}+\lambda\right)\right]^{2}}<0 \\
& \frac{\partial\left(\frac{d e_{t}}{d d_{I S}}\right)}{\partial \lambda}=\frac{\left[1+\beta_{0}\left(\theta_{2}-\theta_{1}\left(\frac{1-v}{v}\right)\right)\right]|D|-\left[-\left[\alpha+\left(\theta_{2}-\theta_{1}\left(\frac{1-v}{v}\right)\right)\right]\left[\left[\lambda-\sigma_{x} \beta_{1}+\left(\theta_{2}-\theta_{1}\left(\frac{1-v}{v}\right)\right)\left(\lambda \beta_{0}-\sigma_{y} \beta_{1}\right)\right]\right.\right.}{|D|^{2}}<0
\end{aligned}
$$

given that $|D|<0, \lambda \beta_{0}-\sigma_{y} \beta_{1}<0$, and $\lambda-\beta_{1} \sigma_{x}<0$.

\section{Estimation and Empirical Evidence}

\section{A. The closed economy}

In this section, we follow Hall (2009), Barro and Redlick (2011), and Karras (2011, 2012) in order to test the hypotheses stated in the previous section. Let's begin with Hall's (2009) equation:

$$
\frac{y_{i, t}-y_{i, t-1}}{y_{i, t-1}}=\theta_{i}+\mu_{t}+m^{g}\left(\frac{g_{i, t}-g_{i, t-1}}{y_{i, t-1}}\right)+u_{i, t}
$$

where $i$ is a subindex for countries and $t$ is a subindex for time. The left side of Equation (16) is the growth rate of real GDP $y_{i, t}$, between two consecutive periods; $g$ stands for real government expenditure, and $\theta_{i}$ and $\mu_{t}$ are country- and time-specific effects, respectively. 
Since the denominator on both sides is $y_{i, t}$, we may interpret $m^{g}$ as the fiscal policy multiplier, assuming that the economy is closed.

Using data from the World Bank and the Penn World Table for Argentina, Bolivia, Brazil, Chile, Colombia, Costa Rica, Ecuador, Guatemala, Honduras, Mexico, Peru, and Venezuela for the years 1980 2014, the empirical results for Equation (16) are presented in Table 1. Even though there are several restrictions in the estimated results (OLS is included for reference), the main conclusion from this table is that in all cases, the estimated coefficient is statistically significant and different from zero, and that these results are consistent with the empirical literature.

Table 1. The closed-economy fiscal multiplier

\begin{tabular}{|l|c|c|c|}
\hline \multirow{2}{*}{ Coefficient } & \multicolumn{3}{|c|}{ Models } \\
\cline { 2 - 4 } & OLS & FE & RE \\
\hline$m^{g}$ & $1.57^{* * *}(0.15)$ & $1.45^{* * *}(0.15)$ & $1.47 * * *(0.14)$ \\
\hline
\end{tabular}

(Note) FE: Country and time fixed effects. RE: Country and time random effects. ***: $1 \%$ significance level. Estimated standard errors in parentheses.

\section{B. Openness}

Considering that the degree of openness to trade might influence the size of the multiplier, Equation (16) could be written as:

$$
\frac{y_{i, t}-y_{i, t-1}}{y_{i, t-1}}=\theta_{i}+\mu_{t}+m^{g}\left(\frac{g_{i, t}-g_{i, t-1}}{y_{i, t-1}}\right)+m^{\text {open }}\left(\frac{g_{i, t}-g_{i, t-1}}{y_{i, t-1}}\right) \text { open }_{i, t}+u_{i, t}
$$

where open $_{i, t}$ is the sum of real exports and imports as a share of the real GDP. The interaction term $\left(\frac{g_{i, t}-g_{i, t-1}}{y_{i, t}}\right)$ open $_{i, t}$ is introduced to capture the effect of openness on the fiscal multiplier. As the denominator is the real output, the estimated coefficient $m^{o p e n}$, can be added to the closed-economy multiplier. Thus, the net effect of fiscal policy on output can be given by a multiplier that varies across countries and over time according to:

$$
m_{i, t}^{g}=m^{g}+m^{o p e n}
$$

Table 2 below shows the estimated results when openness is considered, as shown in Equation (17). According to these estimates, the close economy multiplier remains positive and statistically significant, but the estimated coefficient for the interaction term $\left(\frac{g_{i, t}-g_{i, t-1}}{y_{i, t}}\right)$ open $_{i, t}$, although negative, is not significant. This implies that even when the 
estimated coefficient is not significant, the sign can be negative, suggesting that the fiscal multiplier will become smaller if the economy is open. The overall estimated fiscal multiplier is now 1.08 under FE and 1.21 under RE. However, adding $\left(\frac{g_{i, t}-g_{i, t-1}}{y_{i, t}}\right)$ open $_{i, t}$ to the equation results in an increase of $m^{g}$ from 1.45 to 1.62 under FE (1.47 to 1.59 under RE).

Table 2. The open economy

\begin{tabular}{|l|c|c|c|}
\hline \multirow{2}{*}{ Coefficient } & \multicolumn{3}{|c|}{ Models } \\
\cline { 2 - 4 } & OLS & FE & RE \\
\hline$m^{g}$ & $1.49 * * *(0.31)$ & $1.62 * * *(0.31)$ & $1.59 * * *(0.29)$ \\
\hline$m^{\text {open }}$ & $0.27(0.9)$ & $-0.54(0.83)$ & $-0.38(0.8)$ \\
\hline
\end{tabular}

(Note) FE: Country and time fixed effects. RE: Country and time random effects. $* * *: 1 \%$ significance level. Estimated standard errors in parentheses.

\section{Openness and capital mobility}

As pointed out in the previous section, we argue that openness plays an important role not only on the size of the multiplier but also on the degree of capital mobility. Therefore, Equation (17) can be modified to test the effect of capital mobility on the size of the fiscal multiplier using the interaction term $\left(\frac{g_{i, t}-g_{i, t-1}}{y_{i, t}}\right) k m o b_{i, t}$ as shown in Equation (18):

$$
\begin{aligned}
\frac{y_{i, t}-y_{i, t-1}}{y_{i, t-1}}= & \theta_{i}+\mu_{t}+m^{g}\left(\frac{g_{i, t}-g_{i, t-1}}{y_{i, t-1}}\right) \\
& +m^{\text {open }}\left(\frac{g_{i, t}-g_{i, t-1}}{y_{i, t-1}}\right) \text { open }_{i, t} \\
& +m^{\text {kmob }}\left(\frac{g_{i, t}-g_{i, t-1}}{y_{i, t-1}}\right) \text { kmob }_{i, t}+u_{i, t}
\end{aligned}
$$

where $k m o b_{i, t}$ is a proxy for capital mobility. As a result, once capital mobility has been considered, the net effect of government expenditures on real output would be given by:

$$
m_{i, t}^{g}=m^{g}+m^{o p e n}+m^{k m o b}
$$

Given the fact that there is no such variable for measuring capital mobility, we use Frankel's (1992) approach to select a proxy for capital mobility ${ }^{3}$.

${ }^{3}$ We tried other proxies for capital mobility, but the results were not statistically significant and not better than the ones reported in this 
Frankel (1992) proposed the use of the real interest-rate differential:

$$
k_{i, t}^{m o b}=r_{i, t}-r_{t}^{*}=\left(i_{i, t}-\pi_{i, t}^{e}\right)-\left(i_{t}^{*}-\pi_{t}^{e^{*}}\right)=\left(i_{i, t}-i_{t}^{*}\right)-\left(\pi_{i, t}^{e}-\pi_{t}^{e^{*}}\right)
$$

where $\pi_{i, t}^{e}$ and $\pi_{t}^{e^{*}}$ are the expected domestic rate and foreign inflation rate, respectively.

The estimated results for Equation (18) are presented in Table 3. The empirical evidence shows that the estimated coefficients for the simple fiscal multiplier vary from 1.68 to 1.70 depending on the assumptions used in the estimation. These estimates are statistically significant at $1 \%$ significance level. Second, openness and capital mobility in all estimations have negative coefficients, but not statistically significant; however, the signs and values are in accordance with the empirical literature. Taking a closer look at the estimates, we find that if we add the estimated coefficients, the overall fiscal multiplier will be equal to 1.05 under FE (1.18 under RE). These results suggest that: first, openness and capital mobility reduce the potency of fiscal policy; second, fiscal policy might have some important effects on real output in these Latin American countries; and third, the overall fiscal multiplier becomes smaller when we include openness and capital mobility. The problem is that the coefficients of open and kmob are not statistically significant.

Now, let's take a different look at these results, since there are some other nonapparent results that seem relevant to the discussion. Given the fact that the estimated coefficients for openness and capital mobility are not statistically significant, we can actually see in Tables 1 to 3 that the fiscal multiplier increases from 1.45 to 1.70 under fixed effects ( 1.47 to 1.68 under random effects), after we introduce these variables into the estimation. This implies that openness and capital mobility can enhance the potency of fiscal policy, which may have very important short-run effects on real output. This interpretation is in conflict with the literature.

Table 3. Open economy and capital mobility

\begin{tabular}{|l|c|c|c|}
\hline \multirow{2}{*}{ Coefficient } & \multicolumn{3}{|c|}{ Models } \\
\cline { 2 - 4 } & OLS & FE & RE \\
\hline$m^{g}$ & $1.62 * * *(0.32)$ & $1.69 * * *(0.31)$ & $1.68 * * *(0.30)$ \\
\hline$m^{\text {open }}$ & $0.09(0.87)$ & $-0.65(0.83)$ & $-0.50(0.80)$ \\
\hline$m^{k m o b}$ & $-9.98 e-5 *(5.95 e-5)$ & $-6.36 e-5(5.49 e-5)$ & $-7.14 e-5(5.38 e-5)$ \\
\hline
\end{tabular}

(Note) FE: Country and time fixed effects. RE: Country and time random effects. ***, *: 1\% and 10\% significance level. Estimated standard errors in parentheses.

In order to have a closer look at this issue, we control for openness and capital mobility 
and modify Equations (17) and (18) to obtain:

$$
\frac{y_{i, t}-y_{i, t-1}}{y_{i, t-1}}=\theta_{i}+\mu_{t}+m^{g}\left(\frac{g_{i, t}-g_{i, t-1}}{y_{i, t-1}}\right)+\gamma_{1} \text { open }_{i, t}+u_{i, t}
$$

and

$$
\frac{y_{i, t}-y_{i, t-1}}{y_{i, t-1}}=\theta_{i}+\mu_{t}+m^{g}\left(\frac{g_{i, t}-g_{i, t-1}}{y_{i, t-1}}\right)+\gamma_{1} \text { open }_{i, t}+\gamma_{2} k m o b_{i, t}+u_{i, t}
$$

By introducing open $_{i, t}$ and $k m o b_{i, t}$ this way, we can interpret the estimated coefficient $\mathrm{m}^{g}$ as the overall fiscal multiplier. By doing this, we can determine whether the fiscal multiplier in fact increases with capital mobility. Estimated results are reported in Table 4. The estimated coefficient for openness, although positive in almost all cases, is not statistically significant under either FE or RE. Moreover, the estimated coefficient for capital mobility, although small, is statistically significant at the 5\% significance level under fixed effects ( $10 \%$ under random effects). However, the estimated values for $m^{g}$ vary between 1.43 and 1.47 and are statistically significant at the $1 \%$ significance level. These coefficients are not very different from those reported in Table 1.

Comparing results from Tables 3 and 4, we see that the fiscal multiplier does not diminish as we progressively introduce openness and capital mobility to the equation, contrary to what traditional economic theory predicts. This is a very important result and shows that the hypothesis derived from the theoretical model from Section 3 cannot be rejected. This implies that the effects of fiscal policy in Latin American countries tend to be very similar to those in closed economies. Latin American economies indeed are not very open, and their financial markets are very small and not fully integrated into the rest of the world. As a result, their fiscal policies are very effective in increasing real outputs; however, they might also cause deep contractions if their government spending contracts, considering the procyclical fiscal policies in most Latin American countries. It amplifies the cycle of economic activity.

Table 4. Open economy and capital mobility

\begin{tabular}{|l|c|c|c|c|c|c|}
\hline Coefficient & OLS & FE & RE & OLS & FE & RE \\
\hline \multirow{2}{*}{$m^{g}$} & $1.71^{* * *}$ & $1.43^{* * *}$ & $1.47^{* * *}$ & $1.71^{* * *}$ & $1.43^{* * *}$ & $1.47^{* * *}$ \\
& $(0.15)$ & $(0.15)$ & $(0.14)$ & $(0.15)$ & $(0.15)$ & $(0.14)$ \\
\hline \multirow{2}{*}{$\gamma_{1}$} & $0.06 * * *$ & 0.02 & 0.0003 & $0.065^{* * *}$ & 0.03 & -0.005 \\
& $(0.01)$ & $(0.02)$ & $(0.01)$ & $(0.006)$ & $(0.02)$ & $(0.01)$ \\
\hline \multirow{2}{*}{$\gamma_{2}$} & & & & $-1.03 e-6$ & $-3.43 e-6 * *$ & $-2.70 e-6 * *$ \\
& & & & $(1.61 e-6)$ & $(1.56 e-6)$ & $(1.50 e-6)$ \\
\hline
\end{tabular}

(Note) FE: Country and time fixed effects. RE: Country and time random effects. $* * *, * *$ and $*: 1 \%, 5 \%$, and $10 \%$ significance level. Estimated standard errors in parentheses. 


\section{A dynamic model}

The models presented in Equations (16) to (20) are very useful and an excellent starting point but lack a dynamic structure that can show not only the short run but also the long-run effects. As a result, the dynamic version of the closed-economy model presented in Equation (16) could be written as:

$$
\frac{y_{i, t}-y_{i, t-1}}{y_{i, t-1}}=\theta_{i}+\mu_{t}+\sum_{j=1}^{j} \alpha_{j} \frac{y_{i, t}-y_{i, t-j-1}}{y_{i, t-j-1}}+\sum_{j=0}^{j} m_{j, i, t}^{g}\left(\frac{g_{i, t-j}-g_{i, t-j-1}}{y_{i, t-j-1}}\right)+u_{i, t}
$$

where $j$ is the number of lags and $\alpha^{\prime}$ s and $m^{\prime}$ s are the coefficients to be estimated. Equations (22) and (23) are the corresponding dynamic versions of Equations (19) and (20), as shown in the following equations:

$$
\begin{aligned}
& \frac{y_{i, t}-y_{i, t-1}}{y_{i, t-1}}=\theta_{i}+\mu_{t}+\sum_{j=1}^{j} \alpha_{j} \frac{y_{i, t-j}-y_{i, t-j-1}}{y_{i, t-j-1}}+\sum_{j=0}^{j} m_{j, i, t}^{g}\left(\frac{g_{i, t-j}-g_{i, t-j-1}}{y_{i, t-j-1}}\right) \\
& +\sum_{j=0}^{j} \gamma_{j, i, t}^{\text {open }} \text { open }_{i, t}+u_{i, t} \\
& \frac{y_{i, t}-y_{i, t-1}}{y_{i, t-1}}=\theta_{i}+\mu_{t}+\sum_{j=1}^{j} \alpha_{j} \frac{y_{i, t-j}-y_{i, t-j-1}}{y_{i, t-j-1}}+\sum_{j=0}^{j} m_{j, i, t}^{g}\left(\frac{g_{i, t-j}-g_{i, t-j-1}}{y_{i, t-j-1}}\right) \\
& +\sum_{j=0}^{j} \gamma_{j, i, t}^{\text {open }} \text { open }_{i, t}+\sum_{j=0}^{j} \gamma_{j, i, t}^{k m o b} k m o b_{i, t}+u_{i, t}
\end{aligned}
$$

where an approximation for the long-run multiplier in either case is given by

$$
m_{i, t_{L R}}^{g}=\frac{\sum_{j=0}^{j} m_{j, i, t}^{g}}{1-\sum_{j=1}^{j} \alpha_{j}}
$$

Results for Equations (21), (22), and (23) are reported in Table 5 below. These show that the immediate estimated coefficient $m^{g}(0)$, is significant under fixed and random effects and under any specification of the model, remaining quite constant at around 1.39. Under random effects, it increases from 1.38 to 1.44 when we control for openness and capital mobility. As for the long-run multiplier, it increases from 1.43 to 2.0 under FE when we consider all estimated coefficients, regardless of their significance level. However, under random effects, the multiplier changes around 1.40 under different specifications. The $F$-test indicates that all estimated long-run multipliers are statistically significant. Nevertheless, when we consider only the statistically significant coefficients, the estimated values will be higher, remaining relatively constant (around 1.79) under FE and increasing from 1.89 to 1.95 under RE when controlling for openness and capital mobility. According to the $F$-test, all long-run multipliers are statistically significant at the $1 \%$ significant level. The most striking result derived from 
this table is that the estimated fiscal multiplier tends to increase or at least to remain constant when we control for openness and capital mobility. The other result is that in Latin American countries, the estimated short- and long-run multipliers are higher than those reported in the literature for developed countries.

Table 5. Dynamic model

\begin{tabular}{|c|c|c|c|c|c|c|}
\hline \multirow{2}{*}{$\begin{array}{l}\text { Coefficient } \\
\text { (lag) }\end{array}$} & \multicolumn{2}{|c|}{ Closed economy } & \multicolumn{2}{|c|}{ Open economy } & \multicolumn{2}{|c|}{$\begin{array}{c}\text { Open and capital } \\
\text { mobility }\end{array}$} \\
\hline & FE & RE & FE & RE & FE & $\mathbf{R E}^{\#}$ \\
\hline$\alpha(-1)$ & $\begin{array}{l}0.23 * * * \\
(0.05)\end{array}$ & $\begin{array}{c}0.27 * * * \\
(0.05)\end{array}$ & $\begin{array}{c}0.22 * * * \\
(0.05)\end{array}$ & $\begin{array}{l}0.26 * * * \\
(0.05)\end{array}$ & $\begin{array}{l}0.21 * * * \\
(0.05)\end{array}$ & n.a. \\
\hline$\alpha(-2)$ & $\begin{array}{l}0.001 \\
(0.05)\end{array}$ & $\begin{array}{l}0.03 \\
(0.05)\end{array}$ & $\begin{array}{c}0.01 \\
(0.05)\end{array}$ & $\begin{array}{l}0.04 \\
(0.05)\end{array}$ & $\begin{array}{l}0.03 \\
(0.05)\end{array}$ & n.a. \\
\hline$m^{g}(0)$ & $\begin{array}{c}1.39 * * * \\
(0.16)\end{array}$ & $\begin{array}{c}1.38 * * * \\
(0.15)\end{array}$ & $\begin{array}{c}1.40 * * * \\
(0.16)\end{array}$ & $\begin{array}{c}1.43 * * * \\
(0.15)\end{array}$ & $\begin{array}{l}1.39 * * * \\
(0.16)\end{array}$ & n.a. \\
\hline$m^{g}(-1)$ & $\begin{array}{l}-0.23 \\
(0.18)\end{array}$ & $\begin{array}{l}-0.28 \\
(0.17)\end{array}$ & $\begin{array}{l}-0.24 \\
(0.18)\end{array}$ & $\begin{array}{l}-0.30 * \\
(0.18)\end{array}$ & $(0.19)$ & n.a. \\
\hline$m^{g}(-2)$ & $\begin{array}{l}-0.06 \\
(0.17)\end{array}$ & $\begin{array}{l}-0.14 \\
(0.17)\end{array}$ & $\begin{array}{l}-0.05 \\
(0.17)\end{array}$ & $\begin{array}{l}-0.13 \\
(0.17)\end{array}$ & $(0.17)$ & n.a. \\
\hline$\gamma_{1}(0)$ & & & $\begin{array}{l}0.08 * \\
(0.05)\end{array}$ & $\begin{array}{l}0.09 * * \\
(0.04)\end{array}$ & $0.08 * *$ & n.a. \\
\hline$\gamma_{1}(-1)$ & & & $\begin{array}{l}-0.06 \\
(0.05)\end{array}$ & $\begin{array}{l}-0.11 * * \\
(0.05)\end{array}$ & $(0.05)$ & n.a. \\
\hline$\gamma_{1}(-2)$ & & & $\begin{array}{l}0.007 \\
(0.04)\end{array}$ & $\begin{array}{l}0.02 \\
(0.04)\end{array}$ & $\begin{array}{l}0.01 \\
(0.04)\end{array}$ & n.a. \\
\hline$\gamma_{2}(0)$ & & & & & $\begin{array}{c}-3.48 e^{-6 * * *} \\
(1.59 \mathrm{e}-6)\end{array}$ & n.a. \\
\hline$\gamma_{2}(-1)$ & & & & & $\begin{array}{c}2.03 e^{-6} \\
\left(1.67 e^{-6}\right)\end{array}$ & n.a. \\
\hline$\gamma_{2}(-2)$ & & & & & $\begin{array}{l}1.21 e^{-6} \\
\left(1.66 e^{-6}\right)\end{array}$ & n.a. \\
\hline $\begin{array}{c}m_{L R}(F \text {-test }) \\
\text { S.E. }\end{array}$ & $\begin{array}{c}1.43 * * * \\
(0.58)\end{array}$ & $\begin{array}{c}1.37 * * * \\
(0.55)\end{array}$ & $\begin{array}{c}1.44 * * * \\
(0.58)\end{array}$ & $\begin{array}{c}1.43 * * * \\
(0.55)\end{array}$ & $\begin{array}{l}2.0 * * * \\
(0.59)\end{array}$ & n.a. \\
\hline $\begin{array}{c}m_{L R}^{*}(F \text {-test }) \\
\text { S.E. }\end{array}$ & $\begin{array}{c}1.81 * * * \\
(0.17)\end{array}$ & $\begin{array}{c}1.89 * * * \\
(0.16)\end{array}$ & $\begin{array}{c}1.79 * * * \\
(0.17)\end{array}$ & $\begin{array}{c}1.89 * * * \\
(0.35)\end{array}$ & $\begin{array}{c}1.79 * * * \\
(0.17)\end{array}$ & n.a. \\
\hline
\end{tabular}

(Note) \#: Due to near singular matrix, this model could not be estimated. FE: Country and time fixed effects. RE: Country and time random effects. $F$-test. ${ }^{* *},{ }^{* *}$ and ${ }^{*}: 1 \%, 5 \%$, and $10 \%$ significance levels, respectively. 


\section{E. Extended dynamic model}

Since our measurement of government expenditure is less likely to be exogenous than Hall's (2009) or Barro and Redlick's (2009) military expenditure, our estimated multipliers in Equations (16) to (21) may be biased. Therefore, we build a VAR model that takes into account the effects of economic activity over time on government expenditure. This VAR model consists of two equations that can be written as follows:

$$
\begin{aligned}
\frac{g_{i, t}-g_{i, t-1}}{y_{i, t-1}}= & a_{i}+b_{t}+\sum_{j=1}^{j} \varphi_{j} \frac{y_{i, t-j}-y_{i, t-j-1}}{y_{i, t-j-1}}+\sum_{j=0}^{j} \delta_{j}\left(\frac{g_{i, t-j}-g_{i, t-j-1}}{y_{i, t-j-1}}\right) \\
& +\sum_{j=0}^{j} \beta_{j}^{\text {open }} \text { open }_{i, t}+\sum_{j=0}^{j} \beta_{j}^{k m o b} \text { kmob }_{i, t}+u_{i, t}^{g} \\
\frac{y_{i, t}-y_{i, t-1}}{y_{i, t-1}}= & c_{i}+d_{t}+\sum_{j=1}^{j} \alpha_{j} \frac{y_{i, t-j}-y_{i, t-j-1}}{y_{i, t-j-1}}+\sum_{j=0}^{j} \beta_{j}^{u^{g}} \hat{u}_{i, t}^{g} \\
& +\sum_{j=0}^{j} \gamma_{1, j} \text { open }_{i, t}+\sum_{j=0}^{j} \gamma_{2, j} k \text { kmo }_{i, t}+\varepsilon_{i, t}
\end{aligned}
$$

Equation (24) seeks to capture the possible effects of overall economic activity on government expenditure, where $\hat{u}_{i, t}^{g}$ could be interpreted as an exogenous fiscal shock. Therefore, in order to study the effect of a pure and exogenous fiscal shock, we introduce $\hat{u}_{i, t}^{g}$ from (24) into Equation (25), which is equivalent to Equation (23). In this case, the fiscal multiplier is given by $\sum_{j=0}^{j} \beta_{j}^{u^{g}}$. Tables 6 reports a summary of results from Equation (25); note that the complete set of estimates for each case is reported in Table A.6 in the appendix. The evidence suggests that the estimated fiscal multiplier shows mixed results. First, the estimated value for the fiscal multiplier varies between 0.149 and 0.23 under FE (all estimated coefficients are considered, regardless significance levels) and between 0.00 and 0.34 (only statistically significant coefficients are considered).

Table 6. VAR Model - exogenous fiscal shock

\begin{tabular}{|c|c|c|c|c|}
\hline & FE & RE & FE & RE \\
\cline { 2 - 5 } & \multicolumn{2}{|c|}{ All estimated coefficients } & \multicolumn{2}{|c|}{ Only significant coefficients } \\
\hline$\sum_{j=0}^{j} \beta_{j}^{u^{g}}$ & $\begin{array}{c}0.149 \\
(0.21)\end{array}$ & $\begin{array}{c}0.23 \\
(0.20)\end{array}$ & $\begin{array}{c}0.00 \\
(0.21)\end{array}$ & $\begin{array}{c}0.34^{*} \\
(0.20)\end{array}$ \\
\hline
\end{tabular}

(Note) FE: Country and time fixed effects. RE: Country and time random effects $(F$-test). ***,** and *: 1\%, $5 \%$, and $10 \%$ significance levels, respectively. 


\section{F. Robustness}

The empirical results shown in the previous subsections suggest that given the high values of the multiplier, fiscal policies in Latin America might play an important role for economic stabilization in the short run; however, as predicted by macroeconomic theories, its impacts in the long run tend to be rather negligible. In this sense, it is important to check whether these results are sensitive when we control for other variables that might induce a greater use of fiscal policy, e.g., inflation and oil production. For inflation, we construct a variable equal to the number of digits of the inflation rate. If the rate is less than $1 \%$, we use 0 ; if it is equal to 1 and less than $10 \%$, we use 1 ; if it is equal to or greater than 10 and less than $100 \%$, we use 2; if it is equal to or greater than 100 and less than $1000 \%$, we use 3 ; and so on. Similarly, for oil production, we construct a dummy variable with a value of 1 if the country is a producer and 0 otherwise. We consider these control variables because several Latin American countries have suffered severe hyperinflation problems, particularly during the 1980s and 1990s, while others are oil producers and oil price changes might have affected government spending. Results are shown in the appendix in Tables A.1 to A.3 for the static and A.4 to A.7 for the dynamic models. We could only use the number of digits for the inflation rate as a control variable because when using a dummy for oil production, in some cases, the model could not work due to a near-singular matrix problem ${ }^{4}$. When controlling for inflation, the estimated coefficients are not very different from the ones reported in Table 6. In other words, the estimated fiscal multiplier is approximately 0.34. In fact, as the theory predicts, it decreases over time, suggesting that monetary policy might have only temporary effects on real output. These results are consistent with the ones reported in the literature, e.g., Lopez (2016), Gechert (2015), and Ilzetzki, Mendoza, and Végh (2013). As shown in the appendix, even after controlling for inflation and oil production, the estimated results are not sensitive to the control variables.

\section{Discussion and Conclusions}

Since the surge of fiscal policy instruments as a means for recovering the economies affected by the 2008 2009 financial crisis, the debate on fiscal policies' effectiveness in the United States and other countries has attracted much attention. Some argue that fiscal policies' effects vary because they depend upon the size of the multiplier. Besides, the multiplier varies across countries and over time and is determined by the exchange rate, the degree of openness, and the capital mobility, among other factors. Some others argue that during peacetime, fiscal policies are completely ineffective.

In this paper, we argue that fiscal policies might be effective because Latin American economies are somewhat different from developed ones. Given those empirical results, we

${ }^{4}$ These problems might arise because correlations between open and the estimated error from Equation (24) and between the later and real GDP, for instance, are very high. 
conclude that the size of the multiplier tends to increase or remain relatively constant and that the value of the fiscal multiplier is relatively high. This implies that fiscal policies might be very effective in changing output or stimulating the economy not only in the short run but also in the long run. In the short run, the size of the multiplier is around 1.40, while in the long run, it is around 0.34; the cumulative effect is much lower, as theories and some other empirical studies suggest (Lopez 2016, Ilzetzki, Mendoza and Végh 2013, Gonzalez, Lopez, Rodriguez and Tellez 2014, and Costa and Vaz Sampaio 2016).

Finally, fiscal policies in Latin American countries have a much greater impact on their economies than those in developed countries, because the former have more government interventions (e.g., governments tend to play a significant role in producing some of the goods and services). Even though our results point toward this direction, it is important to continue exploring other variables that measure the freedom or control of capital movements in international markets, testing the hypothesis we have stated for Latin America countries.

Received 23 January 2019, Accepted 13 February 2019 


\section{References}

Abbas, S. M., Bouhga-Hagbe, J., Fatás, A. J., Mauro, P., and Velloso, R. C. Fiscal policy and the current account. IMF Economic Review, Palgrave Macmillan; International Monetary Fund, 59(4) (2011): 603-629.

Retrieved from https://ideas.repec.org/a/pal/imfecr/v59y2011i4p603-629.html.

Auerbach, A. \& Gorodnichenko, Y. Measuring the Output Responses to Fiscal Policy. American Economic Journal: Macroeconomics, 4(2) (2012a): 1-27.

Auerbach, A. \& Gorodnichenko, Y. Fiscal Multipliers in Recession and Expansion. National Bureau of Economic Research. Working Paper Series (September 2012). (2012b). Retrieved from: http://www.nber.org/papers/w17447

Auerbach, A. \& Gorodnichenko, Y. How powerful are fiscal multipliers in recessions? NBER Reporter, National Bureau of Economic Research (NBER), Cambridge, MA, Issue. 2 (2015): 21-24

Barro, R. J. Output effects of government purchases. Journal of Political Economy, 89(6) (1981): 1086-1121.

Barro, R. J. Government spending is no free lunch. Wall Street Journal, p. A.17. (22 ${ }^{\text {nd }}$ of January of 2009). Retrieved from https://scholar.harvard.edu/files/barro/files/wsj_ 09_0122_govspendingnofreelunch-2.pdf.

Barro, R.J., and Redlick, C.J. Macroeconomic effects from government purchases and taxes. The Quarterly Journal of Economics, 126(1) (2011): 51-102.

Batini, N., Eyraud, L., Forni, L., and Weber, A. Fiscal Multipliers: Size, Determinants, and Use in Macroeconomic Projections. Fiscal Affairs Department. International Monetary Fund. Tecnical Note 4. (2014).

Retrieved from https://www.imf.org/external/pubs/ft/tnm/2014/tnm1404.pdf.

Baum, A., Poplawski-Ribeiro, M., and Weber, A. Fiscal Multipliers and the State of the Economy. International Monetary Fund Working Paper, No. WP/12/286. (2012). doi: 10.5089/9781475565829.001.

Blanchard, O. and Perotti, R. An empirical characterization of the dynamic effects of changes in government spending and taxes on output. The Quarterly Journal of Economics, 117(4) (2002): 1329-1368.

Retrieved from https://doi.org/10.1162/003355302320935043. 
Christiano, L, M Eichenbaum, and Rebelo, S. When Is the Government Spending Multiplier Large? Journal of Political Economy, 119(1) (2011): 78 -121.

Coenen, G., Erceg, C. J., Freedman, C., Furceri, D., Kumhof, M., Lalonde, R., Laxton, D., Lindé, J., Mourougane, A., Muir, D., Mursula, S., de Resende, C., Roberts, J., Roeger, W., Snudden, S., Trabandt, M., and Veld, J. Effects of fiscal stimulus in structural models. American Economic Journal: Macroeconomics, 4 (1) (2012): 22-68.

doi: $10.1257 / \mathrm{mac} .4 .1 .22$

Corsetti, G., Meier, A., and Muller, G. What determines government spending multipliers? Economy Policy, 27(72) (2012): 521-565.

Retrieve from https://www.imf.org/external/pubs/ft/wp/2012/wp12150.pdf.

Costa, C. and Vaz Sampaio, A. Tax reduction policies and its impacts on Brazilian economy. Revista Economia e Desenvolvimento, 15(1) (2016): 7-23. Retrieved from http://www. periodicos.ufpb.br/ojs/index.php/economia/article/view/32759.

Davig, T. and Leeper, E. M. Monetary-fiscal policy interactions and fiscal stimulus. European Economic Review, 55(2) (2011): 211-227.

Retrieved from https://doi.org/10.1016/j.euroecorev.2010.04.004.

Dellas, H. and Collard, F. Poole in the new Keynesian model. European Economic Review, 49(4) (2005): 887-907.

Retrieved from http://www.sciencedirect.com/science/article/pii/S0014292103000928.

Eggertsson, G B. What Fiscal Policy is Effective at Zero Interest Rates? NBER Macroeconomics Annual 25 (2011): 59-112.

Fazzari, S., Morley, J., and Panovska, I. State-Dependent Effects of Fiscal Policy. UNSW Business School Research Paper No. 2012-27C (August) (2014).

Retrieved from: https://ssrn.com/abstract=2045192

Feldstein, M. and Horioka, C. Domestic saving and international capital flows. The Economic Journal, 9(358) (1980): 314-329.

Fleming, J. M. Domestic financial policy under fixed and under floating exchange rates. IMF Staff Papers, 9 (1962): 369-379. doi:10.2307/3866091.

Fraga, C., Briseño, I., \& Heras, M. Multiplicadores y coordinación fiscal y monetaria en Argentina, Brasil, Chile y México para el desarrollo. Revista Problemas del Desarrollo, 185(47) (abril-junio) (2016): 11-34. Retrieved from http://probdes.iiec.unam.mx. 
Gechert, S. What fiscal policy is most effective? A meta-regression analysis, Oxford Economic Papers, 67(3) (2015): 553-580.

Retrieved from https://doi.org/10.1093/oep/gpv027

González, A., Lopez, M., Rodríguez, N., and Tellez, S. Fiscal policy in a small open economy with oil sector and non-Ricardian agents. Revista Desarrollo y Sociedad, 73 (primer semestre) (2014): 33-69.

Retrieved from: https://revistas.uniandes.edu.co/doi/pdf/10.13043/dys.73.2

Hall, R. E. By how much does GDP rise if the government buys more output? Brookings Papers on Economic Activity, 40(2) (2009): 183-249. Retrieved from http://web.stan ford.edu/ rehall/BPEA\%20Fall\%202009.pdf.

Hall, R. E. The role of consumption in economic fluctuations. In: The American business cycle: continuity and change. (Ed). Roger J. Gordon (1986): 237-255. Chicago and London: University of Chicago Press.

Ilzetzki, E., Mendoza, E. G., and Végh, C. A. How big (small?) are fiscal multipliers? Journal of Monetary Economics, 60(2) (2013): 239-254. Retrieved from http://www.sas.upenn. edu/ egme/pp/MendozaetalJME.pdf

Karras, G. Trade openness and the effectiveness of fiscal policy: some empirical evidence. International Review of Economics, 59(3) (2012): 303-313.

doi: 10.1007/s12232-011-0126-9

Karras, G. Exchange-rate regimes and the effectiveness of fiscal policy. Journal of Economic Integration, 26(1) (2011): 29-44.

Retrieved from http://www.e-jei.org/journal/view. php?doi=10.11130/jei.2011.26.1.29

Lane, P. R., and Milesi-Ferretti, G. M. The external wealth of nations. Mark II. Revised and extended estimates of foreign assets and liabilities, 1970-2004. Journal of International Economics, 73(2) (2007): 223-250.

Retrieved from http://www.sciencedirect.com/ science/article/pii/S0022199607000591.

Laverde, H. Efectividad de la política fiscal sobre la producción y la inequidad en Colombia: 1990-2006. Equidad Desarrollo, 13(2010): 65-81.

Retrieved from https://revistas.lasalle.edu.co/index.php/ed/article/view/207

Lopez, M. Fiscal Multipliers, Oil Revenues, and Balance Sheet Effects. Banco de La República. Borradores de Economía, 976 (2016).

Retrieved from: http://www.banrep.gov.co/es/publicaciones. 
Jorda, O. Estimation and Inference of Impulse Responses by Local Projections. American Economic Review, 95(1) (2005): 161-182.

Mora, J. U. Fluctuaciones económicas en una economía pequeña con dos sectores productivos bajo régimen de cambio flotante. Revista Ecos de Economía, 17(36) (2013): 21-42.

Moura, G. V. Multiplicadores fiscais e investimento em infraestrutura. Revista Brasileira de Economia, 69(1) (2015): 75-104. doi: 10.5935/0034-7140.20150004.

Mundell, R. A. Capital mobility and stabilization policy under fixed and flexible exchange rates. Canadian Journal of Economics and Political Science, 29(4) (1963): 475-485.

Owyang, M, V A Ramey and S Zubairy Are Government Spending Multipliers Greater during Periods of Slack? Evidence from Twentieth-Century Historical Data. American Economic Review Papers and Proceedings 103(3) (2013): 129-34. Retrieved from: http://dx.doi. org/10.1257/aer.103.3.129.

Puig, J. P. Multiplicador del Gasto Público en Argentina. Universidad Nacional de La Plata (abril). Tesis de Maestría. p. 23 (2014).

Retrieved from http://sedici.unlp.edu.ar/handle/10915/37528.

Ramey, V A. Identifying government spending shocks: it's all in the timing. Quarterly Journal of Economics, 126(1) (2011): 51-102.

Ramey,V. A. and Shapiro, M. D. Costly capital reallocation and the effects of government spending. In: Carnegie-Rochester Conference Series on Public Policy, 48 (1998): 145-194. Retrieved from http://www.sciencedirect.com/science/article/pii/S0167223198000207.

Ramey, V A and S Zubairy. Government Spending Multipliers in Good Times and in Bad: Evidence from U.S. Historical Data. NBER Working Paper No. 20719 (2014).

Romer, C., and Bernstein, J. The job impact of the American recovery and reinvestment plan. Mimeo. Council of Economic Advisers (2009).

Riguzzi, M. The impact of different dimensions of openness on the fiscal multiplier. Working Paper, University of Bern (2001). Retrieved from http://www.harrisdellas.net/conferences/ hasliberg11/Openness_Fiscal_Policy.pdf.

Woodford, M. Simple analytics of the government expenditure multiplier. American Economic Journal: Macroeconomics, 3(1) (2011): 1-35. 
Yang, M. C. The effects of openness on the stabilizing role of fiscal policy. (Job Market Paper) University of Illinois at Chicago, Chicago, USA (2016). Retrieved from http://www.mcyyang. com/uploads/4/2/4/2/42420699/openness_and_fiscal_policy_yang.pdf 


\section{Appendix}

Table A1. The closed economy with control variables (Equation 17)

\begin{tabular}{|c|c|c|c|}
\hline \multirow{2}{*}{ Coefficient } & \multicolumn{3}{|c|}{ Models } \\
\hline & OLS & FE & $\mathrm{RE}$ \\
\hline \multicolumn{4}{|l|}{ Control for inflation } \\
\hline$m^{g}$ & $\begin{array}{c}1.57 * * * \\
(0.15)\end{array}$ & $\begin{array}{c}1.44 * * * \\
(0.15)\end{array}$ & $\begin{array}{c}1.47 * * * \\
(0.14)\end{array}$ \\
\hline \multicolumn{4}{|l|}{ Control for oil production } \\
\hline$m^{g}$ & $\begin{array}{c}1.57 * * * \\
(0.15) \\
\end{array}$ & n.a. ${ }^{\#}$ & $\begin{array}{c}1.47 * * * \\
(0.14)\end{array}$ \\
\hline \multicolumn{4}{|c|}{ Control for inflation and oil production } \\
\hline$m^{g}$ & $\begin{array}{c}1.57 * * * \\
(0.15)\end{array}$ & n.a. $\#$ & $\begin{array}{c}1.47 * * * \\
(0.14)\end{array}$ \\
\hline
\end{tabular}

(Note) ${ }^{\#}$ : Due to near singular matrix, this model could not be estimated. FE: Country and time fixed effects. RE: Country and time random effects. $F$-test. $* * *, * *$ and $*: 1 \%, 5 \%$, and $10 \%$ significance levels, respectively.

Table A2. The open economy with control variables (Equation 17)

\begin{tabular}{|c|c|c|c|}
\hline \multirow{2}{*}{ Coefficient } & \multicolumn{3}{|c|}{ Models } \\
\hline & OLS & FE & $\mathrm{RE}$ \\
\hline \multicolumn{4}{|l|}{ Control for inflation } \\
\hline$m^{g}$ & $\begin{array}{c}1.55^{* * * *} \\
(0.31)\end{array}$ & $\begin{array}{c}1.62 * * * \\
(0.31)\end{array}$ & $\begin{array}{c}1.60 * * * \\
(0.29)\end{array}$ \\
\hline$m^{\text {open }}$ & $\begin{array}{l}0.08 \\
(0.87)\end{array}$ & $\begin{array}{l}-0.54 \\
(0.83)\end{array}$ & $\begin{array}{l}-0.41 \\
(0.79)\end{array}$ \\
\hline \multicolumn{4}{|l|}{ Control for oil production } \\
\hline$m^{g}$ & $\begin{array}{c}1.48 * * * \\
(0.32)\end{array}$ & n.a..$^{\#}$ & $\begin{array}{c}1.59 * * * \\
(0.29)\end{array}$ \\
\hline$m^{\text {open }}$ & $\begin{array}{c}0.28 \\
(0.87)\end{array}$ & n.a." & $\begin{array}{l}-0.37 \\
(0.79)\end{array}$ \\
\hline \multicolumn{4}{|c|}{ Control for inflation and oil production } \\
\hline$m^{g}$ & $\begin{array}{c}1.54 * * * \\
(0.32)\end{array}$ & n.a." & $\begin{array}{l}1.59 * * * \\
(0.29)\end{array}$ \\
\hline$m^{\text {open }}$ & $\begin{array}{c}0.10 \\
(0.87) \\
\end{array}$ & n.a." & $\begin{array}{l}-0.39 \\
(0.80) \\
\end{array}$ \\
\hline
\end{tabular}

(Note) ${ }^{\#}$ : Due to near singular matrix, this model could not be estimated. FE: Country and time fixed effects. RE: Country and time random effects. $F$-test. ***,** and *: $1 \%, 5 \%$, and $10 \%$ significance levels, respectively. 
Table A3. The open economy with control variables (Equation 18)

\begin{tabular}{|c|c|c|c|}
\hline \multirow{2}{*}{ Coefficient } & \multicolumn{3}{|c|}{ Models } \\
\hline & OLS & $\mathrm{FE}^{\#}$ & RE \\
\hline \multicolumn{4}{|l|}{ Control for inflation } \\
\hline$m^{g}$ & $\begin{array}{c}1.66^{* * * *} \\
(0.32)\end{array}$ & $\begin{array}{c}1.69 * * * \\
(0.31)\end{array}$ & $\begin{array}{c}1.68 * * * \\
(0.30)\end{array}$ \\
\hline$m^{\text {open }}$ & $\begin{array}{c}0.07 \\
(0.87)\end{array}$ & $\begin{array}{l}-0.65 \\
(0.83)\end{array}$ & $\begin{array}{l}-0.49 \\
(0.80)\end{array}$ \\
\hline$m^{k m o b}$ & $\begin{array}{l}-9.00 e-5 \\
(5.94 e-5)\end{array}$ & $\begin{array}{l}-6.09 e-5 \\
(5.52 e-5)\end{array}$ & $\begin{array}{c}-7.14 e-5 \\
(5.38 e-5)\end{array}$ \\
\hline \multicolumn{4}{|l|}{ Control for oil production } \\
\hline$m^{g}$ & $\begin{array}{c}1.61 * * * \\
(0.33)\end{array}$ & n.a. ${ }^{\#}$ & $\begin{array}{c}1.68 * * * \\
(0.30)\end{array}$ \\
\hline$m^{\text {open }}$ & $\begin{array}{c}0.09 \\
(0.88)\end{array}$ & n.a. ${ }^{\#}$ & $\begin{array}{l}-0.49 \\
(0.81)\end{array}$ \\
\hline$m^{k m o b}$ & $\begin{array}{c}-9.98 e-5 * \\
(5.95 e-5)\end{array}$ & n.a. ${ }^{\#}$ & $\begin{array}{c}-7.14 e-5 \\
(5.38 e-5)\end{array}$ \\
\hline \multicolumn{4}{|c|}{ Control for inflation and oil production } \\
\hline$m^{g}$ & $\begin{array}{c}1.65^{* * * *} \\
(0.32)\end{array}$ & n.a. ${ }^{\#}$ & $\begin{array}{c}1.68 * * * \\
(0.30)\end{array}$ \\
\hline$m^{\text {open }}$ & $\begin{array}{l}-0.05 \\
(0.88)\end{array}$ & n.a..$^{\#}$ & $\begin{array}{l}-0.49 \\
(0.81)\end{array}$ \\
\hline$m^{k m o b}$ & $\begin{array}{l}-8.96 e-5 \\
(5.95 e-5)\end{array}$ & n.a. ${ }^{\#}$ & $\begin{array}{c}-6.63 e-5 \\
(5.40 e-5)\end{array}$ \\
\hline
\end{tabular}

(Note) ${ }^{\#}$ : Due to near singular matrix, this model could not be estimated. FE: Country and time fixed effects. RE: Country and time random effects. $F$-test. ${ }^{* *}, * *$ and $*: 1 \%, 5 \%$, and $10 \%$ significance levels, respectively. 
Table A4. The expanded open economy with control variables (Equation 19 and 20)

\begin{tabular}{|c|c|c|c|c|c|c|}
\hline \multirow{2}{*}{ Coefficient } & \multicolumn{3}{|c|}{ Equation 19} & \multicolumn{3}{|c|}{ Equation 20} \\
\hline & OLS & $\mathrm{FE}$ & RE & OLS & $\mathrm{FE}$ & $\mathrm{RE}$ \\
\hline \multicolumn{7}{|c|}{ Control for inflation } \\
\hline$m^{g}$ & $\begin{array}{c}1.68 * * * \\
(0.15)\end{array}$ & $\begin{array}{c}1.43 * * * \\
(0.15)\end{array}$ & $\begin{array}{c}1.47^{* * *} \\
(0.14)\end{array}$ & $\begin{array}{c}1.67 * * * \\
(0.15)\end{array}$ & $\begin{array}{c}1.43 * * * \\
(0.15)\end{array}$ & $\begin{array}{c}1.47 * * * \\
(0.14)\end{array}$ \\
\hline$\gamma_{1}$ & $\begin{array}{c}0.05 * * * \\
(0.01)\end{array}$ & $\begin{array}{c}0.02 \\
(0.02)\end{array}$ & $\begin{array}{l}-0.001 \\
(0.02)\end{array}$ & $\begin{array}{c}0.04 * * * \\
(0.01)\end{array}$ & $\begin{array}{l}-0.03 \\
(0.02)\end{array}$ & $\begin{array}{l}-0.001 \\
(0.02)\end{array}$ \\
\hline$\gamma_{2}$ & & & & $\begin{array}{c}-3.45 e-6^{*} \\
(1.88 e-6)\end{array}$ & $\begin{array}{c}-3.88 e-6^{*} \\
(1.72 e-6)\end{array}$ & $\begin{array}{c}-2.35 e-6 \\
(1.7 e-6)\end{array}$ \\
\hline \multicolumn{7}{|c|}{ Control for oil production } \\
\hline$m^{g}$ & $\begin{array}{c}1.62 * * * \\
(0.15)\end{array}$ & n.a. ${ }^{\#}$ & $\begin{array}{c}1.47 * * * \\
(0.14)\end{array}$ & $\begin{array}{c}1.62 * * * \\
(0.15)\end{array}$ & n.a. ${ }^{\#}$ & $\begin{array}{c}1.47 * * * \\
(0.14)\end{array}$ \\
\hline$\gamma_{1}$ & $\begin{array}{c}0.04 * * * \\
(0.01)\end{array}$ & n.a. ${ }^{\#}$ & $\begin{array}{l}0.001 \\
(0.02)\end{array}$ & $\begin{array}{c}0.04 * * * \\
(0.01)\end{array}$ & n.a. ${ }^{\#}$ & $\begin{array}{l}-0.003 \\
(0.01)\end{array}$ \\
\hline$\gamma_{2}$ & & & & $\begin{array}{l}-2.23 e-6 \\
(1.66 e-6)\end{array}$ & n.a. ${ }^{\#}$ & $\begin{array}{l}-2.78 e-6^{*} \\
(1.50 e-6)\end{array}$ \\
\hline \multicolumn{7}{|c|}{ Control for inflation and oil production } \\
\hline$m^{g}$ & $\begin{array}{c}1.62 * * * \\
(0.15)\end{array}$ & n.a. ${ }^{\#}$ & $\begin{array}{c}1.47^{* * *} * \\
(0.14)\end{array}$ & $\begin{array}{c}1.62 * * * \\
(0.15)\end{array}$ & n.a..$^{\#}$ & $\begin{array}{c}1.47 * * * \\
(0.14)\end{array}$ \\
\hline$\gamma_{1}$ & $\begin{array}{c}-0.04 * * * \\
(0.01)\end{array}$ & n.a. ${ }^{\#}$ & $\begin{array}{l}0.001 \\
(0.02)\end{array}$ & $\begin{array}{c}0.04 * * * \\
(0.01)\end{array}$ & n.a..$^{\#}$ & $\begin{array}{r}-0.005 \\
(0.01)\end{array}$ \\
\hline$\gamma_{2}$ & & & & $\begin{array}{l}-2.76 e-6 \\
(1.87 e-6)\end{array}$ & n.a. ${ }^{\#}$ & $\begin{array}{c}-2.35 e-6 \\
(1.7 e-6)\end{array}$ \\
\hline
\end{tabular}

(Note) ${ }^{\#}$ : Due to near singular matrix, this model could not be estimated. FE: Country and time fixed effects. RE: Country and time random effects, $F$-test. ***,** and *: $1 \%, 5 \%$, and $10 \%$ significance levels, respectively. 
Table A5.1. Dynamic model. Control variable: inflation

\begin{tabular}{|c|c|c|c|c|c|}
\hline \multirow{2}{*}{$\begin{array}{c}\text { Coefficient } \\
\text { (lag) }\end{array}$} & \multicolumn{2}{|c|}{ Closed economy } & \multicolumn{2}{|c|}{ Equation 21} & \multirow{2}{*}{$\frac{\text { Equation } 22}{\text { FE }}$} \\
\hline & $\mathrm{FE}$ & $\mathrm{RE}$ & $\mathrm{FE}$ & $\mathrm{RE}$ & \\
\hline$\alpha(-1)$ & $\begin{array}{c}0.23 * * * \\
(0.05)\end{array}$ & $\begin{array}{c}0.26 * * * \\
(0.05)\end{array}$ & $\begin{array}{c}0.22 * * * \\
(0.05)\end{array}$ & $\begin{array}{c}0.26 * * * \\
(0.05)\end{array}$ & $\begin{array}{c}0.21 * * * \\
(0.05)\end{array}$ \\
\hline$\alpha(-2)$ & $\begin{array}{l}0.001 \\
(0.05)\end{array}$ & $\begin{array}{c}0.03 \\
(0.08)\end{array}$ & $\begin{array}{c}0.01 \\
(0.05)\end{array}$ & $\begin{array}{c}0.04 \\
(0.05)\end{array}$ & $\begin{array}{l}0.03 \\
(0.05)\end{array}$ \\
\hline$m^{g}(0)$ & $\begin{array}{c}1.39 * * * \\
(0.16)\end{array}$ & $\begin{array}{c}1.38 * * * \\
(0.15)\end{array}$ & $\begin{array}{c}1.40 * * * \\
(0.16)\end{array}$ & $\begin{array}{c}1.43 * * * \\
(0.15)\end{array}$ & $\begin{array}{c}1.39 * * * \\
(0.16)\end{array}$ \\
\hline$m^{g}(-1)$ & $\begin{array}{l}-0.23 \\
(0.18)\end{array}$ & $\begin{array}{l}-0.28 \\
(0.17)\end{array}$ & $\begin{array}{l}-0.24 \\
(0.18)\end{array}$ & $\begin{array}{l}-0.30^{*} \\
(0.18)\end{array}$ & $\begin{array}{l}-0.22 \\
(0.19)\end{array}$ \\
\hline$m^{g}(-2)$ & $\begin{array}{l}-0.08 \\
(0.17)\end{array}$ & $\begin{array}{l}-0.14 \\
(0.17)\end{array}$ & $\begin{array}{l}-0.07 \\
(0.18)\end{array}$ & $\begin{array}{l}-0.14 \\
(0.17)\end{array}$ & $\begin{array}{l}-0.10 \\
(0.18)\end{array}$ \\
\hline$\gamma_{1}(0)$ & & & $\begin{array}{l}0.09^{*} \\
(0.05)\end{array}$ & $\begin{array}{l}0.09 * * \\
(0.04)\end{array}$ & $\begin{array}{l}0.08^{*} \\
(0.05)\end{array}$ \\
\hline$\gamma_{1}(-1)$ & & & $\begin{array}{l}-0.07 \\
(0.05)\end{array}$ & $\begin{array}{c}-0.11 * * \\
(0.05)\end{array}$ & $\begin{array}{l}-0.07 \\
(0.05)\end{array}$ \\
\hline$\gamma_{1}(-2)$ & & & $\begin{array}{l}0.005 \\
(0.04)\end{array}$ & $\begin{array}{c}0.02 \\
(0.04)\end{array}$ & $\begin{array}{c}0.01 \\
(0.04)\end{array}$ \\
\hline$\gamma_{2}(0)$ & & & & & $\begin{array}{l}-3.14 e-6^{*} \\
(1.78 e-6)\end{array}$ \\
\hline$\gamma_{2}(-1)$ & & & & & $\begin{array}{c}2.19 e-6 \\
(1.71 e-6)\end{array}$ \\
\hline$\gamma_{2}(-2)$ & & & & & $\begin{array}{c}1.28 e-6 \\
(1.67 e-6)\end{array}$ \\
\hline
\end{tabular}

(Note) ${ }^{\#}$ : Due to near singular matrix, this model could not be estimated. FE: Country and time fixed effects. RE: Country and time random effects, $F$-test. ${ }^{* * *}, * *$ and $*: 1 \%, 5 \%$, and $10 \%$ significance levels, respectively. 
Table A5.2. Dynamic model. Control variable: oil production ${ }^{\#}$

\begin{tabular}{|l|c|c|}
\hline \multirow{2}{*}{ Coefficient (lag) } & Closed economy & Open economy (Eq. 21) \\
\cline { 2 - 3 } & $\mathrm{RE}^{\#}$ & $\mathrm{RE}^{\#}$ \\
\hline$\alpha(-1)$ & $0.27^{* * *}(0.05)$ & $0.26^{* * *}(0.05)$ \\
\hline$\alpha(-2)$ & $0.03(0.05)$ & $0.04(0.05)$ \\
\hline$m^{g}(0)$ & $1.38^{* * *}(0.15)$ & $1.42 * * *(0.15)$ \\
\hline$m^{g}(-1)$ & $-0.28(0.18)$ & $-0.30 *(0.18)$ \\
\hline$m^{g}(-2)$ & $-0.14(0.17)$ & $-0.13(0.17)$ \\
\hline$\gamma_{1}(0)$ & & $0.09 * *(0.04)$ \\
\hline$\gamma_{1}(-1)$ & & $-0.11 * *(0.05)$ \\
\hline$\gamma_{1}(-2)$ & & $0.02(0.04)$ \\
\hline
\end{tabular}

(Note) ${ }^{\#}$ : Models for Open \& Capital Mobility could not be estimated. ${ }^{\#}$ : Models could not be estimated because of near singular matrix or because random effects requires the number of cross sections be greater than number of coefficients for between estimator. FE: Country and time fixed effects. RE: Country and time random effects, $F$-test. ***,** and *: $1 \%, 5 \%$, and $10 \%$ significance levels, respectively.

Table A5.3. Dynamic model. Control variable: inflation and oil production ${ }^{\#}$

\begin{tabular}{|l|c|c|}
\hline \multirow{2}{*}{ Coefficient (lag) } & Closed economy & Open economy (Eq. 21) \\
\cline { 2 - 3 } & $\mathrm{RE}^{\#}$ & $\mathrm{RE}^{\#}$ \\
\hline$\alpha(-1)$ & $0.26^{* * *}(0.05)$ & $0.26^{* * *}(0.05)$ \\
\hline$\alpha(-2)$ & $0.03(0.05)$ & $0.04(0.05)$ \\
\hline$m^{g}(0)$ & $1.38^{* * *}(0.15)$ & $1.43 * * *(0.15)$ \\
\hline$m^{g}(-1)$ & $-0.28(0.18)$ & $-0.30 *(0.18)$ \\
\hline$m^{g}(-2)$ & $-0.15(0.17)$ & $-0.14(0.17)$ \\
\hline$\gamma_{1}(0)$ & & $0.09 * *(0.04)$ \\
\hline$\gamma_{1}(-1)$ & & $-0.11 * *(0.05)$ \\
\hline$\gamma_{1}(-2)$ & & $0.02(0.04)$ \\
\hline
\end{tabular}

(Note) ${ }^{\#}$ : Models for Open \& Capital Mobility could not be estimated. ${ }^{\#}$ : Models could not be estimated because of near singular matrix or because random effects requires the number of cross sections be greater than number of coefficients for between estimator. FE: Country and time fixed effects. RE: Country and time random effects, $F$-test. ***,** and *: $1 \%, 5 \%$, and $10 \%$ significance levels, respectively. 
Table A6. VAR model (Equation 25)

\begin{tabular}{|l|c|c|}
\hline \multirow{2}{*}{ Coefficient (lag) } & \multicolumn{2}{|c|}{ No control variables } \\
\cline { 2 - 3 } & FE & RE \\
\hline$\alpha(-1)$ & $0.28^{*} * *(0.06)$ & $0.31 * * *(0.05)$ \\
\hline$\alpha(-2)$ & $0.01(0.06)$ & $0.03(0.05)$ \\
\hline$\beta_{j}^{u^{g}}(0)$ & $-0.001(0.21)$ & $0.02(0.19)$ \\
\hline$\beta_{j}^{u^{g}}(-1)$ & $0.29(0.21)$ & $0.34 *(0.20)$ \\
\hline$\beta_{j}^{u^{g}}(-2)$ & $-0.14(0.21)$ & $-0.13(0.20)$ \\
\hline$\gamma_{1}(0)$ & $0.09 *(0.06)$ & $0.11 *(0.05)$ \\
\hline$\gamma_{1}(-1)$ & $-0.07(0.07)$ & $-0.13(0.06)$ \\
\hline$\gamma_{1}(-2)$ & $0.03(0.05)$ & $0.04(0.05)$ \\
\hline$\gamma_{2}(0)$ & $-3.22 e-6^{*}(1.87 e-6)$ & $-3.28 e-6 *(1.72 e-6)$ \\
\hline$\gamma_{2}(-1)$ & $3.93 e-7(1.84 e-6)$ & $9.41 e-7(1.79 e-6)$ \\
\hline$\gamma_{2}(-2)$ & $4.87 e-6^{* * *}(1.79 e-6)$ & $5.13 \mathrm{e}-6^{* * *}(1.72 e-6)$ \\
\hline
\end{tabular}

(Note) FE: Country and time fixed effects. RE: Country and time random effects, $F$-test. ***, ** and *: $1 \%$, $5 \%$, and $10 \%$ significance levels, respectively.

Table A7. Estimated coefficients (Equation 25)

\begin{tabular}{|l|c|c|}
\hline \multirow{2}{*}{ Coefficient (lag) } & \multicolumn{2}{|c|}{ Control variables: Inflation } \\
\cline { 2 - 3 } & FE & RE \\
\hline$\alpha(-1)$ & $0.28^{* * *}(0.06)$ & n.a. \\
\hline$\alpha(-2)$ & $0.01(0.06)$ & n.a. \\
\hline$\beta_{j}^{u^{g}}(0)$ & $-0.001(0.21)$ & n.a. \\
\hline$\beta_{j}^{u^{g}}(-1)$ & $0.29(0.21)$ & n.a. \\
\hline$\beta_{j}^{u^{g}}(-2)$ & $-0.14(0.21)$ & n.a. \\
\hline$\gamma_{1}(0)$ & $0.09 *(0.06)$ & n.a. \\
\hline$\gamma_{1}(-1)$ & $-0.07(0.07)$ & n.a. \\
\hline$\gamma_{1}(-2)$ & $0.03(0.05)$ & n.a. \\
\hline$\gamma_{2}(0)$ & $-3.22 e-6^{*}(1.87 e-6)$ & n.a. \\
\hline$\gamma_{2}(-1)$ & $3.93 e-7(1.84 e-6)$ & n.a. \\
\hline$\gamma_{2}(-2)$ & $4.87 e-6^{* * *}(1.79 e-6)$ & n.a. \\
\hline
\end{tabular}

(Note) FE: Country and time fixed effects. RE: Country and time random effects, $F$-test. ***,** and *: $1 \%$, $5 \%$, and $10 \%$ significance levels, respectively. 